\title{
Implementasi Kompetensi Pedagogik Guru dalam Perencanaan Pembelajaran PKn di SMAN 1 Lubuk Sikaping
}

\author{
Inge Adrian \\ Prodi Pendidikan Pancasila dan Kewarganegaraan \\ FIS Universitas Negeri Padang \\ E-mail: Ingeadrian4@gmail.com
}

\begin{abstract}
ABSTRAK
Artikel ini bertujuan untuk mengetahui implementasi kompetensi pedagogik guru dalam perencanaan pembelajaran PKn di SMA Negeri 1 Lubuk Sikaping. Jenis penelitian ini adalah penelitian deskriptif dengan pendekatan kualitatif. Dalam menentukan sampel penelitian, peneliti menggunakan teknik purposive sampling. Informan dalam penelitian ini adalah Wakil bidang Kurikulum, Wakil bidang Humas, Guru PKn dan sejumlah siswa. Teknik pengumpulan data yang digunakan dalam penelitian ini adalah observasi, wawancara dan studi dokumentasi. Teknik analisis data dalam penelitian yaitu pengumpulan data, reduksi data, penyajian data, penarikan kesimpulan dan verifikasi. Hasil penelitian ini menunjukkan tidak berjalannya implementasi kompetensi pedagogik guru dalam perencanaan pembelajaran akibat pandemic Covid-19, kurang terlaksananya pembelajaran sesuai dengan rancangan yang ada di dalam RPP, kurangnya pemahaman dan pengetahuan guru mengenai IT.
\end{abstract}

Kata Kunci: RPP, Guru, kompetensi pedagogik

\section{ABSTRACT}

This article aims to determine the implementation of teacher pedagogical competence in Civic lesson pan at SMA Negeri 1 Lubuk Sikaping. This type of research is a descriptive study with a qualitative approach. In determining the research sample, researchers used purposive sampling technique. The informants in this study were representatives of the curriculum field, representatives of the field of Public Relations, Civics teachers and students. The data collection techniques used in this research were observation, interview and documentation study. Data analysis techniques in research are data collection, data reduction, data presentation, drawing conclusions and verification. The results of this study indicate the ineffectiveness of the implementation of teacher pedagogical competence in learning planning due to the COVID-19 pandemic, the lack of implementation of learning in accordance with the design in the lesson plan, the lack of understanding and knowledge of teachers about IT.

Keywords: lesson plan, teacher, pedagogic competence 


\section{PENDAHULUAN}

Guru yang profesional adalah guru yang memiliki seperangkat kompetensi (pengetahuan, keterampilan, dan perilaku) yang harus dimiliki dan dikuasai oleh guru dalam melaksanakan tugas keprofesiannya. Kompetensi yang harus dimiliki guru termaktub dalam Undang-Undang Nomor 14 Tahun 2005 tentang Guru dan Dosen pada Bab IV pasal 10 ayat 91, yang menyatakan bahwa "kompetensi guru meliputi kompetensi pedagogik, kompetensi kepribadian, kompetensi sosial, dan kompetensi profesional yang diperoleh melalui pendidikan profesi".

Kompetensi yang dimiliki oleh seorang guru akan menunjukkan kualitas guru dalam mengajar. Salah satu kompetensi yang harus dimiliki oleh seorang guru adalah kompetensi pedagogik. Kompetensi pedagogik merupakan kompetensi yang perlu dikuasai oleh guru karena kompetensi pedagogik adalah kemampuan guru dalam mengelola pembelajaran peserta didik yang meliputi pemahaman terhadap peserta didik, perencanaan dan pelaksanaan pembelajaran, evaluasi hasil belajar, dan pengembangan peserta didik untuk mengaktualisasikan berbagai potensi yang dimilikinya.

Salah satu komponen kompetensi pedagogik yang harus dimiliki seorang guru yaitu Rencana Pelaksanaan Pembelajaran (RPP). Menurut Sanjaya (2011: 59) Rencana Pelaksanaan Pembelajaran adalah program perencanaan yang disusun sebagai pedoman pelaksanaan pembelajaran untuk setiap kegiatan proses pembelajaran. RPP ini dibuat untuk salah satu atau beberapa pertemuan sesuai dengan standar kompetensi dan kompetensi dasar. Namun, dalam pelaksanaan pembelajaran RPP yang digunakan oleh guru sebagian tidak tercermin dalam setiap aktivitas proses pembelajaran, karena guru tidak menjadikan RPP sebagai panduan dalam proses pembelajaran dan dalam pembuatan RPP tidak dibuat secara mandiri namun dibuat atau didiskusikan pada saat MGMP.

Penelitian ini memfokuskan bagaimana implementasi kompetensi pedagogik guru dalam perencanaan pembelajaran PKn di SMA Negeri 1 Lubuk Sikaping. Dalam proses pembelajaran seorang guru harus memahami dengan baik bagaimana implementasi RPP dalam setiap kegiatan pembelajaran. Berdasarkan grand tour yang dilakukan oleh peneliti menunjukkan bahwa guru tersebut masih kurang dalam pengorganisasian waktu yang seharusnya digunakan untuk pencapaian masing-masing indikator yang telah dirancang dalam perencanaan pembelajaran. Hal ini terlihat dari cara mengajar guru yang tidak efektif karena lebih banyak menyampaikan obrolanobrolan ringan sehingga yang seharusnya indikator materi yang akan disampaikan tersebut harus dikembangkan sesuai dengan RPP namun tidak sesuai dengan apa yang telah dirancang sebelumnya. 
Selanjutnya, sebagai seorang guru yang telah menguasai kompetensi pedagogik dan sebagai guru yang profesional harus mampu menguasai materi secara mendalam. Namun disini terlihat bahwasannya guru masih belum mampu menguasai materi pembelajaran yang dirancang secara mendalam. Terbukti dengan guru masih membaca materi yang terdapat dalam Lembar Kerja Siswa (LKS) dan menyampaikan materi dengan metode ceramah dan tanya jawab. Selain itu, RPP yang telah dibuat oleh guru tersebut bukan merupakan rancangan sendiri, melainkan hasil dari rapat guru-guru mata pelajaran atau yang sering disebut dengan MGMP. Sehingga terdapat guru yang tidak menjadikan RPP sebagai panduan dalam proses pembelajaran. Hal ini berkaitan dengan penelitian Tyagita (2018) menyatakan bahwa untuk meningkatkan kompetensi pedagogik guru dapat dilakukan dengan beberapa cara diantaranya melalui MGMP, kursus kependidikan, workshop, supervisi dan rapat sekolah.

Pada dasarnya peningkatan kompetensi pedagogik guru akan menghindarkan kegiatan pembelajaran bersifat monoton, tidak disukai siswa dan membuat siswa kehilangan minat serta daya serap dan konsentrasi belajarnya. Guru PKn di SMA Negeri 1 Lubuk Sikaping, pada kenyataannya tidak sepenuhnya melaksanakan kompetensi yang seharusnya dimiliki. Masih terdapat guru yang kurang mampu mengembangkan potensi diri dan kemampuannya dalam mengajar. Oleh karena itu untuk mencapai tujuan pendidikan nasional, seorang guru harus mampu meningkatkan kompetensi pedagogik yang dimilikinya.

\section{METODE PENELITIAN}

Jenis penelitian ini adalah kualitatif dengan metode studi kasus yang bertujuan untuk menjelaskan implementasi kompetensi pedagogik guru dalam pembelajaran PKn di SMA Negeri 1 Lubuk Sikaping (Sudaryono: 2018). Informan dalam penelitian ini adalah Wakil bidang Kurikulum, Wakil bidang Humas, Guru Pkn dan Siswa. Teknik sampling yang digunakan dalam penelitian ini adalah teknik purposive sampling. Purposive sampling merupakan peneliti menentukan sendiri informan penelitiannya sebagai sumber data berdasarkan kriteria yang ditentukan melalui pertimbangan peneliti berdasarkan maksud dan tujuan peneliti (Sugiyono. 2012: 16). Jenis data dalam penelitian ini adalah data primer dan data sekunder. Teknik pengumpulan data yang digunakan adalah observasi, wawancara dan studi dokumentasi. Uji keabsahan data dilakukan melalui triangulasi sumber. Sumber dan data yang diperoleh akan dianalisi melalui tahap reduksi data, penyajian data dan penarikan kesimpulan. 


\section{HASIL DAN PEMBAHASAN}

\section{Proses Penyusunan Rencana Pelaksanaan Pembelajaran (RPP)}

Berdasarkan Permendikbud Nomor 22 Tahun 2016 dalam penyusunan RPP hendaknya mengacu pada prinsip-prinsip sebagai berikut: (a) perbedaan individual peserta didik; (b) partisipasi aktif peserta didik; (c) berpusat pada peserta didik untuk mendorong semangat, motivasi dan kemandirian; (d) pengembangan budaya membaca dan menulis; (e) pemberian umpan balik dan tindak lanjut RPP; (f) penekanan pada keterkaitan dan keterpaduan antara KD, materi pembelajaran, kegiatan pembelajaran, dan indicator pencapaian kompetensi; (g) mengkomodasikan pembelajaran tematik-terpadu, kemandirian lintas mata pelajaran, lintas aspek belajar, dan keragaman budaya; (h) penerapan teknologi informasi dan komunikasi secara terintegrasi, sistematis, dan efektif sesuai dengan situasi dan kondisi.

Berdasarkan hasil wawancara penulis lakukan dengan seorang guru, beliau mengatakan bahwa dalam merencanakan rancangan dalam pembuatan RPP, terlebih dahulu merencanakan seperti apa pendekatan yang sesuai digunakan dalam pembelajaran, media apa yang tepat digunakan dengan materi pembelajaran yang akan disampaikan dalam proses pembelajaran. Perencanaan ini dilakukan agar rancangan yang dibuat di dalam RPP terlaksana dalam proses pembelajaran dan kegiatan pembelajaran dapat berjalan secara efektif dan efisien sesuai dengan rancangan yang ada di dalam RPP.

Selanjutnya selaku Wakil Kurikulum mengatakan bahwa seorang guru yang profesional harus mampu membuat RPP sendiri. Sebelum membuat RPP guru terlebih dahulu merencanakan atau melihat unsurunsur yang harus dilihat dalam pembuatan RPP. Dengan menyusun rencana pembelajaran secara sistematis dan berdayaguna maka guru akan mampu melihat, mengamati, menganalisis, dan memprediksi program pembelajaran sebagai kerangka kerja yang terencana sehingga pembelajaran dapat berjalan secara efektif dan efisien.

Peneliti menemukan bahwa guru PKn di SMA N 1 Lubuk Sikaping sudah mampu merencanakan penyusunan RPP yang mengacu kepada unsur-unsur yang harus diperhatikan dalam penyususnan RPP. Sebagai seorang guru yang profesional dan kompeten di dalam bidangnya, guru harus merumuskan perencanaan awal dalam penyusunan RPP agar RPP yang dibuat bisa dijadikan pedoman dalam proses pembelajaran.

\section{Pelaksanaan Rencana Pelaksanaan Pembelajaran}

Pelaksanaan RPP merupakan proses yang dilakukan dalam rangka menyampaikan bahan pelajaran sesuai dengan rancangan yang ada di dalam RPP. Setiap guru berkewajiban menyusun RPP secara lengkap dan sistematis agar pembelajaran berlangsung secara interaktif, inspiratif, menyenangkan, menantang, efisien, memotivasi peserta didik untuk berpartisipasi aktif dalam proses pembelajaran. 
Komponen-komponen dalam rencanan pelaksanaan pembelajaran mengacu kepada Permendikbud Nomor 22 Tahun 2016 adalah sebagai berikut, (a) identitas sekolah; (b) identitas mata pelajaran atau tema/ subtema; (c) kelas/ semester; (d) materi pokok; (e) alokasi waktu; (f) tujuan pembelajaran yang dirumuskan berdasarkan KD; (g) kompetensi dasar dan indicator pencapaian; (h) materi pembelajaran; (i) metode pembelajaran; (j) media pembelajaran; (k) sumber belajar; (I) langkah-langkah pembelajaran dilakukan melalui tahap pendahuluan, inti, dan penutup; $(m)$ penilaian hasil pembelajaran. Pada pelaksanaan RPP termuat beberapa langkah yaitu kegiatan pembuka, kegiatan inti, dan kegiatan penutup.

Berdasarkan wawancara, observasi dan studi dokumentasi, peneliti menemukan bahwa dalam pelaksanaan rencana pelaksanaan pembelajaran guru PKn di SMA $\mathrm{N} 1$ Lubuk Sikaping belum melaksanakan secara maksimal komponen pelaksanaan RPP pada saat proses pembelajaran.

\section{Kendala-kendala yang ditemui Guru dalam Mengimplementasikan Kompetensi Pedagogik dalam Perencanaan Pembelajaran PKn}

\section{Kurangnya pemahaman dan pengetahuan guru mengenai IT}

Teknologi informasi dan komunikasi menjadi tuntutan kompetensi yang harus dimiliki seorang guru untuk melaksanakan tugasnya, sehingga setiap guru harus siap untuk terus belajar TIK guna untuk terus meningkatkan kompetensi tersebut. Menurut Sari E N dan Asmaningrum dalam Sutria (2020: 521), menyatakan bahwa TIK memiliki fungsi dalam proses pembelajaran yaitu sebagai media/ alat bantu dalam proses pembelajaran, adapun fungsi TIK dalam proses pembelajaran dapat berupa alat bantu guru untuk mengajar, media belajar untuk siswa, dan alat bantu interaksi guru dan siswa.

Berdasarkan wawancara, observasi dan studi dokumentasi yang peneliti lakukan, kendala yang ditemui guru yaitu kurangnya pemahaman dan pengetahuan mengenai IT. Hal ini disebabkan oleh kurangnya keinginan guru untuk mempelajari IT, keinginan menambah wawasan mengenai IT dan kurangnya pelatihan untuk guru mengenai IT.

Sebagaimana yang dikemukakan oleh Muhammad (2012: 235) menyatakan bahwa guru selaku tenaga pengajar perlu menguasai IT karena mereka selalu menjalankan profesinya sebagai tenaga pengajar. Sehingga dengan demikian sebelumnya guru harus dibekali dengan pengetahuan tentang IT. Dengan penguasaan IT, diharapkan guru mampu mengajar lebih baik, efisien, dan efektif sehingga anak didiknya lebih mudah memahami materi yang diajarkan.

\section{Kesulitan dalam menyiapkan media pembelajaran untuk memperlancar pencapaian KD}

Di dalam proses pembelajaran guru mengalami kesulitan dalam menyiapkan media pembelajaran disebabkan oleh ketidakmampuan 
guru dalam menggunakan teknologi. Penyebab lainnya masih terdapat guru yang tidak memanfaatkan teknologi seperti laptop, LCD sebagai media pembelajaran, hal lainnya yaitu guru jarang membuat media pembelajaran. Hal tersebut selaras dengan yang disampaikan oleh Wiyani dalam Kinasih (2017: 6) menyampaikan bahwa media pembelajaran memberikan dampak yang positif dalam kegiatan pembelajaran, meskipun demikian dalam kenyataannya ternyata masih jarang guru mendayagunakan media pembelajaran sebagai alat untuk membantu meningkatkan kegiatan pembelajaran.

Kesulitan guru dalam menyiapkan media pembelajaran dikarenakan guru merasa kesulitan jika mengoperasikan alat tersebut sendiri. Guru beranggapan bahwa dengan menggunakan media pembelajaran membuat kegiatan pembelajaran malah tidak dapat berjalan dengan yang diharapkan. Kendala tersebut didukung dengan pendapat Rahman dalam Kinasih (2017: 9) bahwa guru tidak menggunakan media pembelajaran disebabkan karena guru merasa khawatir tidak dapat mengoperasikan media pembelajaran. Terkadang sebagian guru masih belum dapat menyesuaikan diri dengan perkembangan teknologi. Misalnya guru masih takut salah klik, apalagi jika guru memang tidak pernah belajar dan membiasakan diri untuk menggunakan media pembelajaran.

\section{Terbatasnya pengetahuan guru terkait pengembangkan materi pelajaran}

Guru sebagai sumber belajar memiliki peran yang sangat penting. Peran guru sebagai sumber belajar berkaitan erat dengan penguasaan materi pelajaran. Ketika seorang guru dapat menguasai materi pelajaran dengan baik, maka ia benar-benar sebagai sumber belajar bagi anak didiknya. Selain itu guru yang menguasai materi pembelajaran secara mendalam dapat dilihat dari perencanaan pengembangan pembelajaran yaitu dalam RPP. Berdasarkan wawancara dan observasi yang peneliti lakukan, dalam hal menguasai materi pembelajaran guru PKn masih memiliki keterbatasan pengetahuan dan wawasan terkait dengan materi pembelajaran. Hal ini disebabkan oleh kurangnya minat guru dalam membaca dan kurangnya keinginan guru untuk mencari materi dari sumber-sumber lainnya. Sebagaimana yang dikatakan Anugraheni (2017: 209) menyatakan bahwa hambatan guru dalam mengembangkan bahan ajar dikarenakan guru masih kurang menguasai materi yang akan diajarkan, terbatasnya buku pegangan guru dan buku siswa.

\section{KESIMPULAN}

Implementasi kompetensi pedagogik guru dalam perencanaan pembelajaran PKn belum terlaksana dengan optimal karena banyak rancangan yang ada di dalam RPP tidak terlaksana dalam proses pembelajaran. Bukan hanya itu dalam pelaksanaan pembelajaran sesuai dengan RPP guru masih mengalami beberapa kesulitan dalam 
mengimplementasikan dan kegiatan dalam proses pembelajaran tidak sesuai dengan rancangan yang ada di dalam RPP. Kesulitan yang ditemui guru dalam mengimplementasikan kompetensi pedagogik dalam perencanaan pembelajaran PKn yaitu kurangnya pemahaman dan pengetahuan guru mengenai IT. Kesulitan dalam menyiapkan media pembelajaran untuk memperlancar pencapaian kompetensi dasar, dan masih terbatasnya pengetahuan guru terkait pengembangan materi pembelajaran.

\section{DAFTAR PUSTAKA}

Balqis, Petri dkk. 2014. Kompetensi Pedagogik Guru dalam Meningkatkan Motivasi Belajar Siswa pada SMPN 3 Ingin Jaya Kabupaten Aceh Besar. Jurnal Administrasi Pendidikan, Volume 2, No. 1.

Dahnial, Irfan. 2017. Analisis Kompetensi Guru PKn dalam Menerapkan Kurikulum 2013 di SMP Negeri Sekecamatan Stabat. Jurnal Tematik, Volume 6, No.4.

Fitriani dkk. 2017. Kompetensi Pedagogik Guru dalam Pengelolaan Pembelajaran di MTsN Muhammadiyah Banda Aceh. Jurnal Administrasi Pendidikan. Volume 5, No.2.

Habibullah Ahmad. 2012. Kompetensi Pedagogik Guru. Edukasi, Volume 10, No.3.

Hamdani. 2017. Hubungan Kompetensi Pedagogik dan Motivasi Mengajar dengan Hasil Belajar Siswa Kelas IX pada Mata Pelajaran Fikih di MAN 2 Model Medan. Jurnal Ansiru, volume 1, Nomor 1.

Latifah, Nurul. 2018. Kompetensi Pedagogik Guru PPKN (Studi tentang Perencanaan Pembelajaran di SMK Binawiyata Sragen). Prosiding Seminar Nasional PPKn.

Riyan, Cepi. 2010. Peningkatan Kompetensi Pedagogik Guru Melalui Penerapan Model Education Centre Of Teacher Interactive Virtual (Educative). Jurnal Penelitian Pendidikan, Vol. 11, No.1.

Tyagita, Brigitta Putri Atika. 2018. Strategi Peningkatan Kompetensi Pedagogik Guru Untuk Meningkatkan Mutu Sekolah. Jurnal Manajemen Kependidikan. Volume 5, No.2 